\title{
Analysis the Internalization of Core Values at UNIDA Gontor Business Unit
}

\author{
Fajar Surya Ari Anggara* \\ Program Studi Manajemen, Universitas Darussalam Gontor \\ Jalan Raya Siman Kecamatan Siman Kabupaten Ponorogo, Indonesia \\ fajarsurya@unida.gontor.ac.id \\ Wahyu Widodo \\ Program Studi Manajemen, Universitas Darussalam Gontor \\ Jalan Raya Siman Kecamatan Siman Kabupaten Ponorogo, Indonesia \\ wahyuwidodo253@gmail.com
}

Diterima: 24-05-2021 | Disetujui: 24-12-2021 ｜ Dipublikasi: 31-01-2022

\section{ABSTRAK}

Penelitian ini bertujuan untuk mendapatkan hasil analisa bagaimana internalisasi nilai-nilai dasar dalam unit bisnis Universitas Darussalam Gontor dalam pengembangan sumber daya manusia. Penelitian ini dilakukan dengan menggunakan penelitian lapangan. Penelitian dilakukan Unit Bisnis Universitas Darussalam Gontor yang beralamatkan di Jalan Raya Siman Kecamatan Siman Kabupaten Ponorogo, Provinsi Jawa Timur. Informan dalam penelitian ini meliputi 1 orang Direktur Utama, 2 orang Manajer Perusahaan, 2 orang staf yang juga sebagai mahasiswa, dan 1 orang karyawan tetap pada Unit Bisnis Universitas Darussalam Gontor. Dalam penelitian ini jenis observasi yang digunakan partisipasi pasif artinya peneliti tidak ikut terlibat dalam kegiatan Unit Bisnis Universitas Darussalam Gontor. Peneliti melakukan wawancara dengan sistem bebas namun tetap terkontrol, dimana interview melakukan dengan bebas apa yang akan dilakukan oleh interview kepada interviewer namun tetap mengarah pada pembicaraan. Hasil penelitian menunjukkan bahwa pelaksanaan internalisasi nilai-nilai dasar yang meliputi keikhlasan, kesederhanaan, kemandirian, ukhuwah islamiyah atau kebersamaan, dan kebebasan dalam pengembangan sumber daya manusia Unit Bisnis Universitas Darussalam Gontor telah sesuai dengan teori tahapan-tahapan internalisasi, strategi internalisasi, metode pelatihan dan pengembangan dan memiliki fungsi untuk meningkatkan moral dan akhlak sumber daya manusia. Perlu dilakukan analisis lebih lanjut secara kuantitatif seperti menganalisis variabel yang berpengaruh untuk meningkatkan kinerja Unit Bisnis Universitas Darussalam Gontor.

Kata Kunci:

Internalisasi; Nilai Dasar; Panca Jiwa; Unit Bisnis

\begin{abstract}
This research aims to obtain the results of an analysis of how to internalize basic values in the business unit of the University of Darussalam Gontor in human resource development. This research was conducted using field research. The research was conducted by the Business Unit of The University of Darussalam Gontor, located on the Siman Highway, Siman Subdistrict, Ponorogo Regency, East Java Province. Informants in this study include 1 President Director, 2 Company Managers, 2 Staff who are also Students, and 1 Permanent Employee in the Business Unit of The University of Darussalam Gontor. In this study, the type of observation used passive participation means that researchers are not involved in the Business Unit activities of The University of Darussalam Gontor. Researchers conduct interviews with a free but controlled system, where the interview does freely what the interview will do to the interviewer but still leads to talks. The results showed that the implementation of internalization of basic values including Sincerity, Simplicity, Independence, Ukhuwah Islamiyah or Togetherness, and Freedom in the development of human resources Business Unit Darussalam Gontor University has been in accordance with the theory of internalization stages, internalization strategy, training and development methods and has a function to improve the moral and moral human resources. Further quantitative analysis is needed, such as analyzing influential variables to enhance the performance of the Business Unit of Universitas Darussalam Gontor.
\end{abstract}

Keywords:

Internalization; Basic Values; Panca Jiwa; Business Unit 


\section{INTRODUCTION}

The Business Unit of Universitas Darussalam Gontor (U3) is one of the businesses built by the campus institutions themselves, and this business is managed by lecturers, UNIDA Gontor students and also employees who work in each unit. This effort was established to improve and advance an independent economy at the University of Darussalam Gontor itself. Before establishing this business of course there is careful planning prepared by the leaders of the institution which is then handed over to the manager of $\mathrm{U} 3$, after which there is a name of organizing, implementation and control. In this business of course each individual without exception employees is responsible for implementing management functions that have been determined from the beginning. After all is done all the businesses in U3 are instilling in themselves each with the five souls of PMDG which should be. Make a nitty gritty elaboration for the required values internalization vital arrangement equipped towards giving responsibility to individuals of the authority group custom-made to the auxiliary complexity of the internalization of values (Essawi \& Tilchin, 2012).

Knowledge and morality are required in the process of human resource development in order to create quality human resources. As the Prophet (peace and blessings of Allah be upon him) said: Today's Muslim activity should be better than yesterday and tomorrow better than today. The value in the message can be instilled into each employee by using internalization to improve the competence of workers for example: programs, training, education, and human resource development (Suci, 2020).

The business unit of UNIDA Gontor has to develop by looking at the additions of businesses under the name U3, as well as employees who began to grow from before. The challenge for the administration is to create confidence within the organization's capacity to convey tough goals. They have to propel the organizations to attain objectives and to center their consideration within the long run to internalize unused capabilities(Anwar \& Hasnu, 2013).

Refer to (Rahmat \& Juwana, 2018) stated that Islamic values are flexible at all levels of the organization. Presenting Islam in the organization turns out to have an impact on improving the performance and revenue of business organizations. Instill the value of five souls in a University of Darussalam Gontor Business Unit will be better when connected with the management function, in addition to good business will also be more blessings in running a business in general and has a positive difference compared to the businesses.

While cultural theory emphasizes internalized beliefs and values, empirical research often mainly focuses on the attribution of values and beliefs to organizational leaders. The focus of this article is on internalizing core values approach on Business Unit University of Darussalam Gontor and how to implement management functions in The Business Unit of Universitas Darussalam Gontor. According to the report, organizations should regain their integrity by ensuring that control mechanisms are integrated into the structure and functions of their organizational culture (Ekwutosi \& Moses, 2013).

The application of management functions in general should be applied in every company, but on Business Unit University of Darussalam Gontor (U3) that instill five properties of the five souls in 
Pondok Modern Darussalam Gontor (PMDG) namely, the soul of sincerity, the soul of simplicity, the soul of self-reliance, the soul of Islamic brotherhood and the soul of freedom. The current research will be conducted in a business unit located and managed by the University of Darussalam Gontor who have conducted the application of the "Panca Jiwa" values in each working group, where life in this university is imbued by the atmospheres that we can deduce in the five souls.

\section{RESEARCH METHOD}

This type of research is qualitative research, this method is based on the philosophy of post positivism used to research on the condition of natural objects, (as opposed to experiments) where researchers as a key instrument, data collection techniques are carried out in combination, data analysis is qualitative, and the results emphasize more meaning than generalization. The researcher can make inductive observations on this qualitative research, because the purpose of this qualitative research is to achieve an understanding of how people feel in the process of their lives, give meaning and describe how people interpret their experiences about internalizing basic values in applying the principles of management principles in the Business Unit of The University of Darussalam Gontor.

In this study located in UNIDA Gontor business unit to obtain the validity of data in perfect data processing. The object that will be interviewed by the researcher is the main management of this business, which is the perpetrator of the organization and he who is concerned with this business unit including the management functions that have been applied to this organization.

To clarify and ensure this research the author will focus the problems that will be discussed today, at this time researchers have the scope of the research so as not to become a widespread research. The scope of the research conducted by the current author is only limited to research on how to internalize the value of the five souls in the management of the business unit of the University of Darussalam Gontor which is only done to limit the scope of research and focus on objects related to the current title of research. In the current study, the author only discussed how internalization of the value of five souls in the management of business units of The University of Darussalam Gontor obtained from the methods. This method includes interviewing, observation and from the management of the company to know by analyzing how internalization of the value of the five souls in the management of this business unit. Whether from the application of the management function there is a nature of the five souls embedded in the nature of each individual perpetrator of this organization.

Population is a generalized area consisting of: objects/subjects that have a certain quantity and characteristics set by researchers to be studied and then drawn conclusions. One person can be used as a population, because one person has characteristics, such as his speaking style, personal discipline, hobbies, how to get along, leadership and others. The population taken by this research are all actors of organizations working in UNIDA Gontor business units. The sample chosen by the researchers in UNIDA Gontor business unit is the first president director of this business unit, a manager, two staff, and then two employees of the business unit, so the total sample taken is six people, from six people 
who will be interviewed by the researcher as follows: President Director, Two Company Managers as S1 Service, Two Student Staff, and One Fixed Staff.

The data collection technique has several methods, including observation. This method is carried out by researchers because it will be directly involved in observation at all times, through the observation of researchers learning about the behavior and meaning of the behavior. An interview is a meeting of two people to get the information needed by the interviewer from the source of the question and answer, so that it can be constructed in a particular topic. Documentation is a record of some important events that have passed. Documents that can be used as research materials include the yearend report of UNIDA Gontor Business Unit.

The data analysis used by the current authors uses the analysis methods of Miles and Huberman (1984), which suggests that activities in qualitative data analysis are conducted interactively and continue continuously until complete. The analysis uses three steps, Data Reduction, Data Presentation, and Conclusion Drawing. Reduction of data obtained from a considerable amount of fields in this study needs to be recorded in detail and thoroughly. Data reduction means choosing the main things, summarizing, focusing on the things that matter, and finding patterns and themes and making things unnecessary.

In presenting the data on the current qualitative research, the research can be done in the form of a brief description, narrative, chart of the relationship between the category and its type, it will make it easier for researchers in understanding and planning their next work. Withdrawal of conclusions, which qualitative conclusions may be able to answer the formulation of problems contained in the beginning and even vice versa, because in qualitative research the problems studied are still temporary and can change according to development.

\section{RESULT AND DISCUSSIONS}

Internalizing basic values to $\mathrm{U} 3$ employees in applying the principles of management principles, is a step taken by UNIDA Gontor Business Unit in realizing Islamic human resource performance. There are 4 management principles that are the basis of the management of UNIDA Gontor Business Unit (U3). The first aspect is Planning Management. From the results of interviews to respondents that the application of planning in the Business Unit is with a work program in the form of writing. The second aspect is organizing management. From the interview results, respondents one, two, four and six stated that the placement of employees in this Business Unit is based on selection. And respondents three and five stated the placement of employees in this business unit based on ability and suitability. Conforming to A positive human health perspective on how spiritual leadership weaves its influence on employee safety performance: The role of harmonious safety passion that spiritual leadership builds workers' sense of autonomous purpose by using mutual social power mechanisms and a bottom-up interactional approach. This allows them to autonomously internalize work experiences through their identities (Ali et al., 2020). 
The third aspect is Implementation Management. From the results of interviews to respondents that the implementation in the Business Unit is to implement the existing work program in the form of writing. The director may also build work difficulties by rewarding employees who do a good job, increasing the number of outreach programs to the community about service policies and standards, reprimanding employees who offer services that do not meet the provisions, and providing direction and instruction to employees about how to execute the service (Kuswati, 2020).

The fourth aspect is Supervisory Management. From the results of the interview, respondents one, two, three and five stated that the supervision conducted by the director of the Business Unit on employees is by reporting in the form of writing on a weekly basis. And respondents four and six stated the supervision of employees in this business unit is directly by the manager of the Business Unit. The initial stage in the implementation of business corporate governance by building the commitment of the company's ranks and building the foundation that is the basis for the implementation of the commitment of governance supervisory (Priyono, 2019) .

The management of UNIDA Gontor Business Unit not only aims to improve the company's performance but these values are embedded in the daily attitudes and behaviors of its employees outside the UNIDA Gontor Business Unit. Of course, the process of internalizing these values is not easy because each individual employee has brought the value of themselves and surely the value is not always the same as what the company wants. In agreement with the study about the Effect of Spiritual Leadership on Employee Effectiveness: An Intrinsic Motivation Perspective that Employees who have internalized the corporate vision through their belief structures regard sharing technical expertise as a personally worthwhile realization. This research supports the concept that spiritual leadership is essential for supporting employees' job success, knowledge sharing behaviors, and innovation behaviors (Wang et al., 2019).

There are five basic values in the UNIDA Gontor Business Unit. The first value is the Soul of Sincerity. From the results of the interview, respondents one, two, five and six stated that the internalization of the value of sincerity conducted by the director of the Business Unit to employees is to give a talk with the theme of sincerity. And respondents three and four stated by way of assignment. Islamic value-based management can be started from sincere in trying, trust in all transactions, concern for the welfare of the community and the environment, fairness and transparency in all activities, practicing knowledge, realizing pride in the work / workforce, and consultation with stakeholders before decision making (Niati et al., 2020).

The second value is the Soul of Simplicity. From the results of the interview, respondents one, two, five and six stated that the internalization of simplicity values carried out by the director of the Business Unit to employees is from the service and attitude. Simplicity does not imply passivity. This soul is a valuable resource for developing a persistent mindset in the face of adversity. Simplicity denotes a steady and supportive source of ability, patience, and self-control in the face of life's challenges(Syamsuri \& Saputro, 2019). 
The Third Value is the Soul of Self-Reliance. From the results of the interview, respondents one, two, four, five and six stated that the internalization of the value of Self-reliance carried out by the director of the Business Unit to employees is to provide tasks to be completed independently. And the third respondent stated that to bring up his own initiative in managing the Business Unit. According to the study of Pondok Pesantren al-Istiqlal can be seen that the life of students is carried out simply, the fulfillment of food needs is done simply by cooking alone, and other patterns of life and learning. This condition shows that the students in this boarding school show descriptively the pattern of self-reliance in life (Uci sanusi, 2012).

The fourth Value is the Spirit of Brotherhood. From the results of the interview, respondents one stated that the internalization of the value of brotherhood conducted by the director of the Business Unit to employees is by means of caring for each other. Respondents two, three, four and six stated in the manner of the association. And five respondents started by working together. As reported on The Conceptual Framework of Islamic Work Ethic (IWE) that Muslims are brothers to one another, according to the principle of ukhuwah (brotherhood). It implies that a person's life and consciousness should be unified in terms of ideas and behavior (Norlela Kamaluddin \& Manan, 2010) .

The fifth value is the Soul of Freedom. From the results of the interview, that respondent one stated that the internalization of the value of freedom carried out by the director of the Business Unit to employees is by freeing up to re-initiate. Respondents two, four and five stated in a freeway in applying their respective knowledge. And respondents three and six stated in a free way to do and complete all the tasks given. All of these freedoms are of course by remaining under the supervision of superiors. As stated in Spiritual Leadership: Meaning in the Sustainable Workplace article that spiritual awareness is used to view events, conditions, and issues from a holistic viewpoint, resulting in employee wellbeing and independence, which reduces negative aspects of work such as stress (Samul, 2020).

From the results of the interview to the respondents the strategy of internalizing the value of Panca Jiwa by the director of the Business Unit in employees is to hold a gathering and recitation every day conducted after Dzuhur prayers. And gathered there are several activities such as congregational prayers, reading the Qur'an together, memorizing short letters and then giving advice in the form of lectures from directors and managers of business units. The reaction of all employees in this Business Unit with this strategy they received sincerely.

\section{CONCLUSION AND RECOMMENDATION}

The application of management functions in the Business Unit of the University of Darussalam Gontor, the application of planning management in the Business Unit that is done by recording the planning in the form of writing. The application of organizing management in the placement of employee positions is to use selection. Implementation management in the Business Unit in carrying out the work on the organization that is by working on what has been written programmed work at the beginning of planning. Management control in the Business Unit is the supervision carried out by the 
Anggara, F.S.A. \& Widodo, W. (2022). Analysis the Internalization of Core Values at ....

director of the company to all employees and staff by the way the association is held weekly and monthly, from the association the director controls from the form of reports. The Director of UNIDA Gontor Business Unit instills the value of sincerity to employees by giving direction in the form of input on sincerity during the association and also the provision of work tasks in the form of responsibilities. And the value of the soul of employee simplicity is by emphasizing to employees to use simple clothes according to the nature of the cottage, and also by providing basic tools or facilities. The value of selfreliance is by giving them a task in the form of work and it is recommended to be able to complete it yourself without any help from other parties. And instill a teamwork spirit that is by holding a gathering once a week because of the association can strengthen and arise a sense of kinship. And instill the spirit of freedom by giving freedom in applying an idea, innovation and expertise that they have. The director's strategy in instilling the values of Panca Jiwa to employees is to hold lectures such as recitation together after Dzuhur prayers and giving lectures on the values of Panca Jiwa conducted by the director of the company. The next answer about how all employees react with this strategy is sincerity. To get results of analysis about the performance of Universitas Darussalam Gontor's Business Unit improvement, more quantitative analysis, such as analyzing influential variables, is needed. 


\section{REFERENCES}

Ali, M., Aziz, S., Pham, T. N., Babalola, M. T., \& Usman, M. (2020). A positive human health perspective on how spiritual leadership weaves its influence on employee safety performance: The role of harmonious safety passion. Safety Science, 131 (July), 104923. https://doi.org/10.1016/j.ssci.2020.104923

Anwar, J., \& Hasnu, S. (2013). Ideology, Purpose, Core Values and Leadership: How they influence the Vision of an Organization? International Journal of Learning and Development, 3(3), 168. https://doi.org/10.5296/ijld.v3i3.3642

Ekwutosi, O. C., \& Moses, O. S. (2013). Internalization of Organizational Culture: A Theoretical Perspective. International Journal of Business Tourism and Applied Sciences, 1(2), 77-96.

Essawi, M., \& Tilchin, O. (2012). Structural approach to changing organizational cultural values. International Journal of Business and Social Science, 3(20), 173-180.

Kuswati, Y. (2020). The Influence of Organizational Culture on Employee Performance. Budapest International Research and Critics Institute (BIRCI-Journal): Humanities and Social Sciences, 3(1), 296-302. https://doi.org/10.33258/birci.v3i1.761

Niati, N., Tanjung, H., \& Yasid, M. (2020). Prophet Muhammad (PBUH) Business Management In Organizational Development (Case Study Of Wikrama-Bogor Vocational School). Jurnal Manajemen, 11(1), 01. https://doi.org/10.32832/jm-uika.v11i1.2692

Norlela Kamaluddin, \& Manan, S. K. A. (2010). The Conceptual Framework Of Islamic Work Ethic (Iwe). Malaysian Accounting Review, 9(Vol. 9 No. 2), 57-70. https://doi.org/10.1016/S01406736(81)90797-2

Priyono, S. (2019). Jurnal Ekonomi dan Bisnis Islam Concept And Implementation of Good Corporate Governance In Sharia Banking In Indonesia Jurnal Ekonomi dan Bisnis Islam. Ad-Deenar Jurnal Ekonomi Dan Bisnis Islam, 3(2), 113-144. https://doi.org/10.30868/ad.v3i2.553

Rahmat, I., \& Juwana, L. (2018). Working Islamic Management: Sebuah Best Practice Internalisasi Islam Dalam Organisasi Bisnis Kuliner. JEBIS (Jurnal Ekonomi Dan Bisnis Islam), 3(1), 103. https://doi.org/10.15548/jebi.v3i1.148

Samul, J. (2020). Spiritual Leadership : Meaning in the Sustainable Workplace. Sustainability, 12(1), 267. https://doi.org/https://doi.org/10.3390/su12010267 
Anggara, F.S.A. \& Widodo, W. (2022). Analysis the Internalization of Core Values at ....

Suci, R. D. (2020). Internalisasi Nilai-Nilai Etika Bisnis Islam Dalam Pengembangan Sumber Daya Manusia (Studi Kasus Ayam Penyet Surabaya Cabang. http://repository.iainpurwokerto.ac.id/8744/

Syamsuri, S., \& Saputro, Y. E. (2019). Panca Jiwa As Social Capital Approach: an Alternative Strategy for Islamic Economic Development. Jurnal Ekonomi Dan Keuangan Islam, 7(2), 180-203. https://doi.org/10.22373/share.v7i2.2668

Uci sanusi. (2012). Pendidikan Kemandirian di Pondok Pesantren (Studi Mengenai Realitas Kemandirian Santri di Pondok Pesantren Al-Istiqlal Cianjur dan Pondok Pesantren Bahrul Ulum Tasikmalaya). Pendidikan Agama Islam -Ta'lim Vol. 10 No. 2 - 2012, 10(2), 139.

Wang, M., Guo, T., Ni, Y., Shang, S., \& Tang, Z. (2019). The effect of spiritual leadership on employee effectiveness: An intrinsic motivation perspective. Frontiers in Psychology, 9(JAN), 1-11. https://doi.org/10.3389/fpsyg.2018.02627 